\title{
Article
}

\section{Giant Alcohol: A Worthy Opponent for the Children of the Band of Hope}

Mcallister, Annemarie

Available at http://clok.uclan.ac.uk/13242/

Mcallister, Annemarie ORCID: 0000-0003-0615-3262 (2014) Giant Alcohol: A Worthy Opponent for the Children of the Band of Hope. Drugs: Education, Prevention and Policy, 22 (2). pp. 103-110. ISSN 0968-7637

It is advisable to refer to the publisher's version if you intend to cite from the work. http://dx.doi.org/10.3109/09687637.2014.977227

For more information about UCLan's research in this area go to http://www.uclan.ac.uk/researchgroups/ and search for < name of research Group>.

For information about Research generally at UCLan please go to http://www.uclan.ac.uk/research/

All outputs in CLoK are protected by Intellectual Property Rights law, including Copyright law. Copyright, IPR and Moral Rights for the works on this site are retained by the individual authors and/or other copyright owners. Terms and conditions for use of this material are defined in the policies page.

\section{CLoK}

Central Lancashire online Knowledge www.clok.uclan.ac.uk

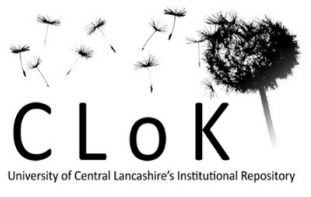


GIANT ALCOHOL - A WORTHY OPPONENT FOR THE CHILDREN OF THE BAND OF HOPE

Short title: Giant Alcohol - a worthy opponent 
GIANT ALCOHOL - A WORTHY OPPONENT FOR THE CHILDREN OF THE BAND OF HOPE

\section{$\underline{\text { Abstract }}$}

From its foundation in 1847, the temperance organisation the Band of Hope addressed its young members as consumers, victims, and agents. In the first two roles they encountered the effects of drink of necessity, but in the third role they were encouraged to seek it out, attempting to influence individuals and wider society against 'Giant Alcohol'.

With an estimated membership of half the school-age population by the early twentieth century, well over three million, the Band of Hope also acted more directly to influence policy, and encouraged young people to consider issues of policy and politics. With its wide range of activities and material to educate, entertain and empower millions of children, and its radical view of the place of the child, the Band of Hope not only mobilised its child members to lobby for legal change, including prohibition, but took an active part in pointing out the cost of alcohol to society, particularly during the 14-18 war. The organisation began to decline post 1918, and this paper focuses on the address made to children by the Band of Hope in the late nineteenth and early twentieth centuries, at a time when its innovative view of children as able to understand and influence policy decisions reflected developments in the construction of childhood. This article draws on the archive of the British National Temperance League, over 50,000 items located in the Livesey Collection, University of Central Lancashire. 
GIANT ALCOHOL - A WORTHY OPPONENT FOR THE CHILDREN OF THE BAND OF HOPE

\section{INTRODUCTION}

The archetypal temperance song 'Father, dear Father, come home with me now' might seem over-sentimental to modern tastes, but it undoubtedly represented the experience of some poor families, depicting a child dying from hunger and neglect as his father drinks the family's money away. 'But it is significant that this song, and many others, features a child watching over, advising, and implicitly reproaching her father - and such responsibility is taken as a fact of child life, even if a sad one. The repeated refrain, which begins 'Hear the sweet voice of the child,' acts to draw attention to this role, in which a little girl is the voice of wisdom. Children in the temperance movement were not only encouraged to think of themselves as having independent power to judge and advise their parents, but even represented as having a duty to do so. Examination of the material provided by the Band of Hope, the temperance movement for children founded in 1847 and still existing under the name of Hope UK today, provides plentiful examples of encouragement to such agency - and to further social or political action.

Space does not permit a detailed history of the temperance movement and its social and cultural importance in the nineteenth and twentieth centuries, but it is important to note that concepts of liberation, self-improvement and self-determination were central to the origins of the total abstinence movement (see Harrison, 1994, Berridge, 2013, and McAllister, 2014). 'Temperance' had become understood as complete abstinence for most of the movement by the 1840s, and this presented, of course, a much clearer message than moderation. This 'teetotal' principle avoids potentially confusing debate as to what 'moderation' might consist of, and presents 
drink as so powerful and volatile that a single drink may put one on the road to the hospital, the poorhouse or the jail. Therefore, the argument goes, the only way to avoid risk is to avoid drink entirely. Risk avoidance, therefore, was at the heart of teetotallism and the agents for encouraging risk prevention were often children. Many temperance organisations were closely linked with Christian belief or set up under the auspices of religious groups, and moral responsibility was also appealed to, as well as enlightened self-interest. It is as well to remember that deeper resonances operated after formal links with religion had begun to decay; as lain Wilkinson remarks, 'Within a secularized cosmology, risk adopts the traditional mantle of sin' (2001: 4). In the material which this paper considers, the risks which alcohol could present were frequently and uncompromisingly linked with sin, which individuals and society were shown as having a duty to oppose.

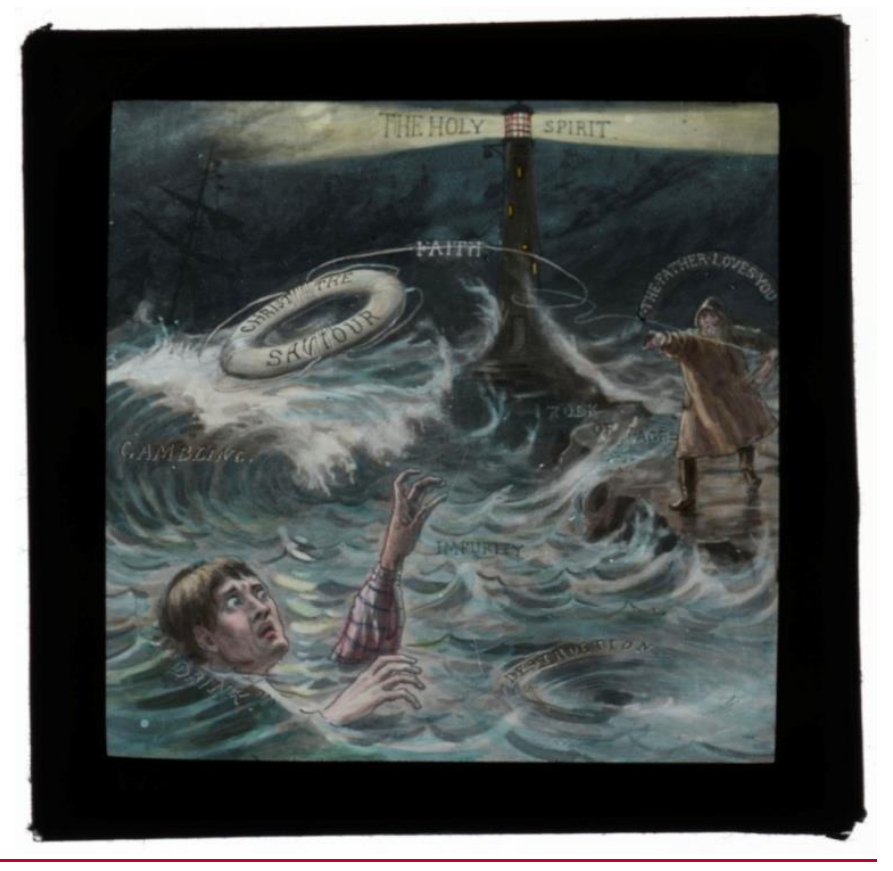

Figure 1 makes explicit the interventionist role which members of the total abstinence, or 'teetotal' movement were expected to fulfil with respect to alcohol. This magic lantern slide, part of a flexible Victorian technology which was widely 
used in the temperance movement for performances to children as well as adults, shows Everyman in the metaphorical sea of life. The swell which poses the most imminent danger is 'Drink.' But the most significant point is that, although 'Christ the Saviour' brings salvation, this would not be possible without the agency of the coastguard, who has spotted the drowning man and acted to throw him the allimportant lifeline.

\section{CHILDREN AND ALCOHOL: THE BAND OF HOPE}

But why was it considered vitally important to give children this message, in the nineteenth and twentieth centuries? It is easy to assume that children have always been constructed as protected subjects, but in fact this is at odds with historical evidence. Not only were the majority of children in the nineteenth century, and earlier, seen as part of the labour force, but they were of necessity exposed to all aspects of life - including death, disease, and a wide variety of behaviour from the people around them. Children were given alcohol medicinally or as a common sedative, child workers were sometimes paid in pubs, and children were in any case seen as useful consumers by those selling drink (see Gutzke,1984; McAllister, 2011). It was only in 1886, for example, that the sale of alcoholic drinks to children under 13 was banned, and in 1889 G.R. Sims could write in How the Poor Live of seeing mothers give babies gin-and water, 'the process is called 'giving the young'un a taste." (cited in Gutzke, 77). If children did not themselves seek escape or conviviality in alcohol, they might well encounter adults who drank, and in many cases children were victims of poverty or neglect as a result of parental overconsumption. This came to be seen on a larger scale as threatening 'national racial vitality' by the end of the nineteenth century, as theories of inherited physical, mental and moral deterioration intersected with concerns about women drinking and the 
unhealthy environment in public houses (Gutzke, 78). Sims's subsequent influential series of six articles, called The Cry of the Children (1907) both drew on and influenced contemporary debate by its linking of maternal drinking and infant mortality, greatly influencing the 1908 Children's Bill which completely excluded children under 14 from licensed premises.

. The Band of Hope began as a group of about 300 poor children in Leeds in 1847, and its rapid growth was extraordinary, even by the standards of nineteenth-century temperance organisations. A few months later there were sixteen meetings being held regularly in Leeds, with a total membership of over 4,000 , and Bands had been set up in other industrial centres and villages in the North of England, and subsequently the rest of the UK, with the first London Band in 1848. The organisation grew dramatically: by 1878 half a million members were claimed nationally, by 1886 over 1.5 million, by 1892 over 2.5 million and by 1897, the golden jubilee of the movement, membership was estimated at over 3 million. Over 3.5 million members were claimed by 1901 and this remained steady until 1914.i This represented a very high 'market reach': in 1911, for example, out of a school population of 6 million, over 3.5 million children had signed the pledge and were members of children's temperance societies (Williams and Brake, 1980: 181). Meetings were held at least once a week, with lectures, interactive activities, and lantern shows, and those who could afford the charge paid a subscription of a weekly halfpenny. This fee entitled them to a monthly Band of Hope magazine, containing more temperance teaching. Regular public events such as processions, galas and concerts maintained their identification with the temperance community. Children became members by signing the teetotal pledge, usually only from the age of seven, although many younger children attended meetings, and it is important to 
bear in mind the comparative youth of many members when considering the complexity of propaganda material discussed later in this paper. The nondenominational Christian line preserved by the organisation ensured that Bands could be formed independently or attached to Sunday Schools, which was undoubtedly an important factor in the growth of the organisation (see Shiman, 1973).

The Band of Hope Publications Department was a powerhouse of the UK temperance movement, becoming the largest producer of magic lantern slides and a major publisher of periodicals, books, and pamphlets, thereby influencing the way in which millions of children were taught to regard alcohol - and to see their duty as opposing personal indulgence and perceived state complicity. In this fight, children were often encouraged to see themselves as David, in a suitably biblical analogy. The young David, armed only with a slingshot and God's approval, had slain the giant Goliath who had been thought invincible by the strongest adult champions.

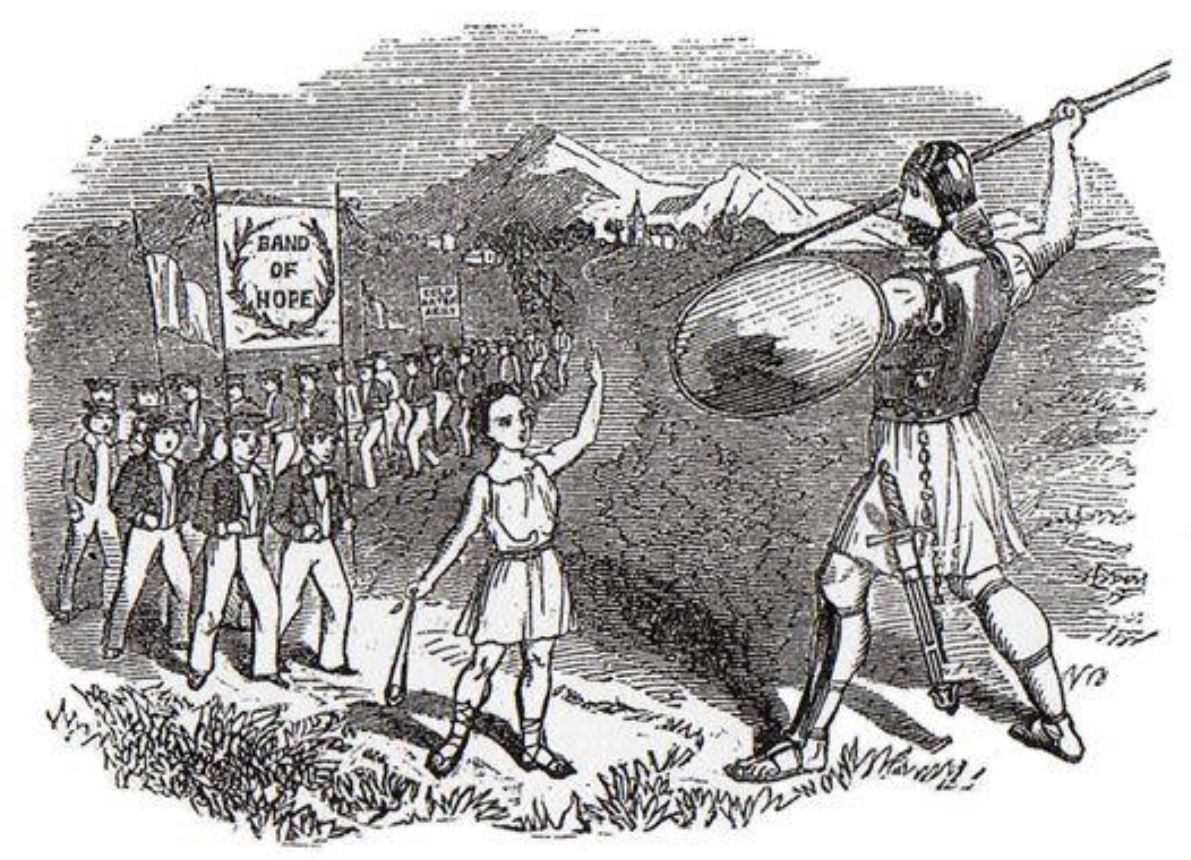


Figure 2 shows the boy David, fighting the Giant Alcohol, supported by a children's army. It provided a graphic message for the child readers of The Band of Hope Review (1851-1937), the main Band of Hope journal which achieved a circulation of 250,000 , more than several adult temperance publications combined (cited in Harrison, 1994: 308). Much Band of Hope iconography does show children as being protected from risk of harm, often by guardian angels or female personifications of abstract concepts such as Religion or Motherhood, but many other images, as well as recitations, stories and songs, depict children in energetic and challenging roles. A song such as 'A Million More! - The Children's Song,' printed in an 1891 issue of a magazine for volunteer workers, The Band of Hope Chronicle (1868-1983) provides a representative sample of the many martial songs regularly supplied, to be sung by children. The final verse is particularly interesting, and is given below,

Then come and join our Band everywhere throughout the land,

Let us show the grown-up people how it's done!

How the children some despise can be good and brave and wise,

And through children (sic italics) shall the victory be won!

\section{REFRAIN}

Come, boys, come and join our army!

Come, girls, come and lead the way!

Till another million strong, we will fight against the wrong,

And for ever drive the curse of drink away! lii 
The tune is a rousing march, as were many more such as 'O Come! And Join Our Army' (1873) and 'Temperance Battle Song' (1885). .' Song titles reveal the way in which children were encouraged to feel that they could make a contribution to the fight, from 'Little Ones Like Me' (1865) to 'Arise, Ye Brave!' (1883). In many others, such as 'The Lifeboat Crew' (1869) and 'Pull Together, Boys!' (1870), the young singers are represented as crewing the Band of Hope lifeboat, with a mission of rescuing drinkers. The lifeboat was a recurrent metaphor for temperance activity in Band of Hope material.

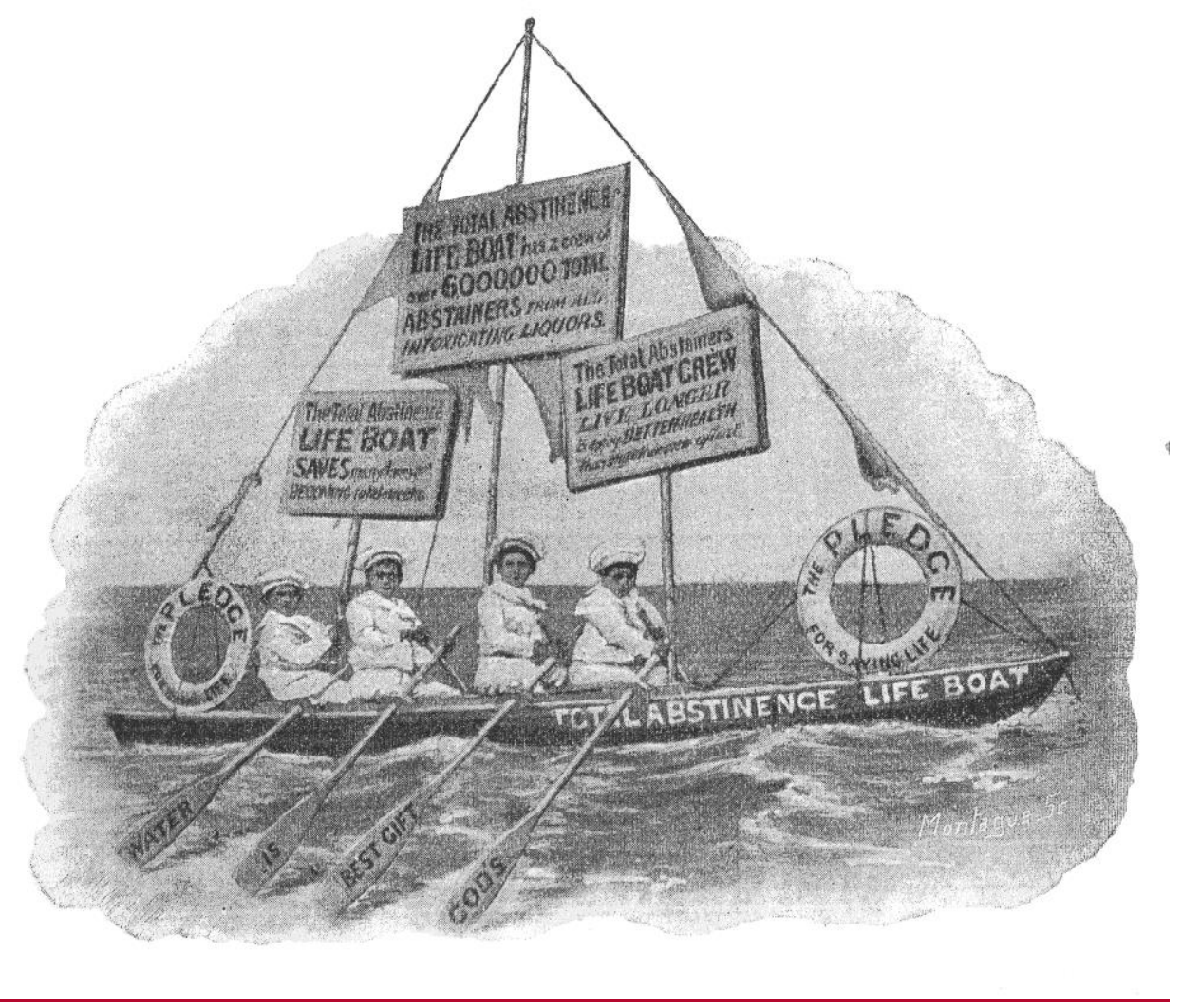

\section{THE CHANGING CONSTRUCTION OF CHILDHOOD}

In Juvenile Nation (2014), Stephanie Olsen discusses the importance of the informal education provided by voluntary organisations such as the Band of Hope during the period 1880-1914, and its focus on citizenship and the shaping of character. She 
argues that this period sees 'the emergence of a modern conception of childhood' (1) with the 'child exemplar ...[who] could shape not only his child peers, but also the adults in his life' (4). Widespread concerns about social problems, racial degeneration and national efficiency at this period led to a focus upon children's moral potential as future citizens (Springhall, 1977; Gutzke,1984; Berridge, 2013). Organisations such as the Boys' Brigade (1883) and the Scout Movement (1908) emerged, but the Band of Hope had been addressing its members as responsible citizens for decades. The origins of teetotalism in radical individualism, and the links of some writers or groups with the 'evangelical code' (Brown, 2013), had led to a stress on children as responsible agents in temperance material. Songs encouraged them to challenge family and friends, from 'Don't Marry a Man If He Drinks!' (1868) to 'Brother, what are you doing?' (1879) and 'Father, won't you try? (1881).Temperance stories for children often featured them reversing roles with adults, not only knowing better than them but monitoring and reproving them. An illustrative example is The Little Captain by Linde Palmer, excerpted in the Band of Hope magazine Onward (1865-1910) in 1867. Here the eldest son of the poverty-stricken Grey family, forced to move to a poor area due to father's drinking, takes on the local gang and forms them into a group of 'Cold Spring Volunteers' to reclaim their drunken parents. Ironically, he dies of hunger before his own father finds the strength to forswear drink, but his dying words administer a final warning which converts his father. From the 1880s even more stress was laid upon children's responsibilities in Band of Hope material, reflecting current cultural concerns about the future of the nation and moral leadership, and the it was understood that the young members had a mission is to intervene in adult society on the personal and political level, exercising a protective function. ${ }^{v}$ Some versions of the Band of Hope pledge even overtly reminded the 
young entrant of their responsibility to others by featuring the text of St Paul's epistle to the Romans (14:21), 'It is good neither to eat flesh nor to drink wine nor anything whereby thy brother stumbleth or is offended or is made weak.' But child members were expected to go further than merely setting an example, by engaging in active agency.

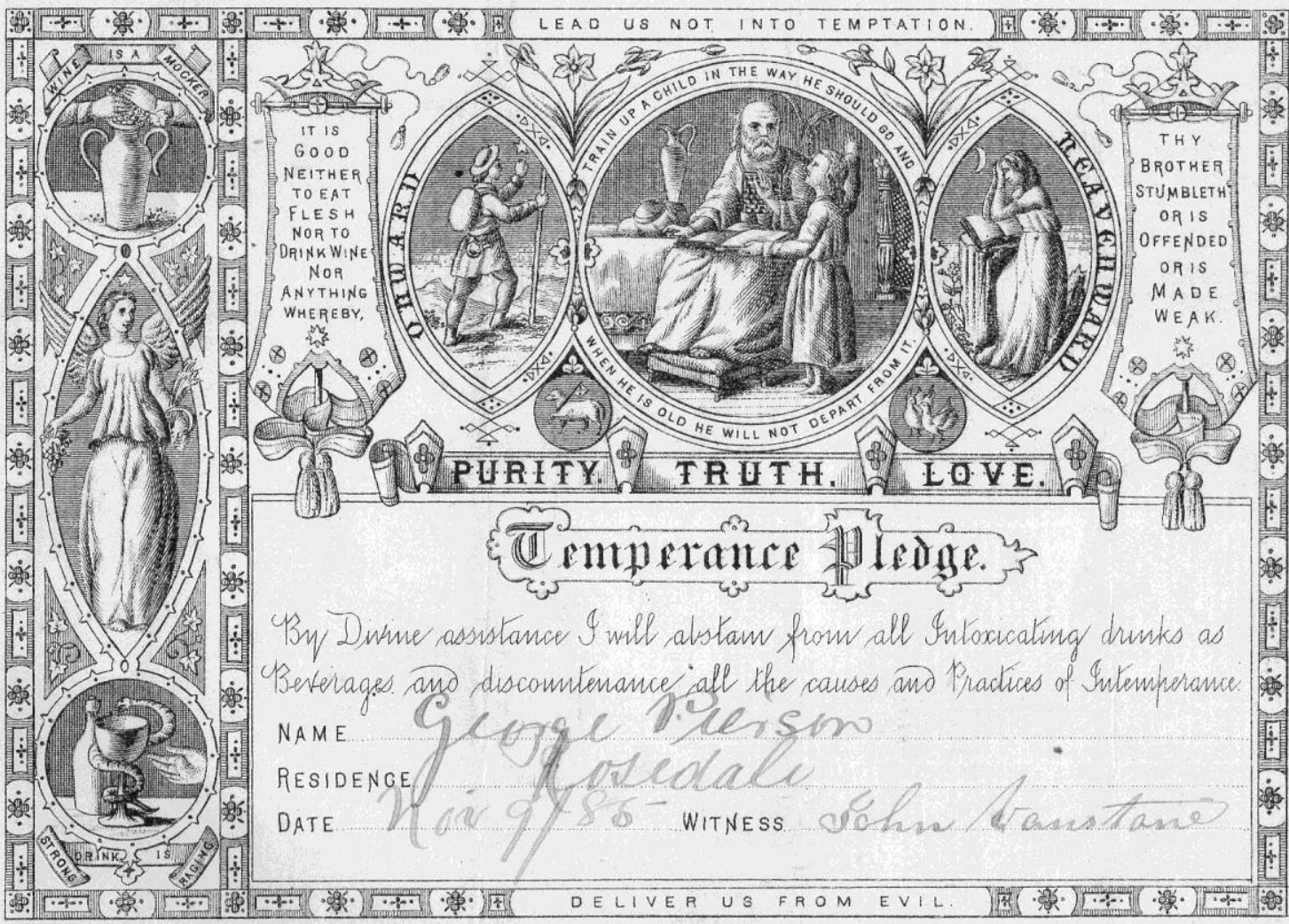

Published by the Lancashire ANd Cheshire BAND of Hope UnIon, 43 Market Street, Manchester-Copyright

Thanks to the teaching material and magazines provided for them, these agents were well-drilled in teetotal principles.

\section{SPREADING THE MESSAGE}

The arguments used to persuade hearers or readers into temperance changed their focus to reflect developments in approaches to the 'problem' of Drink in society. The individualistic stress on moral conviction and conversion of the 1830 s and 40 s, the 
links with radical liberalism of the 1860 s and 70 s, the 'scientific' focus of the 1880 s and the concerns about national deterioration and Social Darwinism of the 1890s all influenced the way in which alcohol was presented to Band of Hope members in successive decades (see Berridge, 2013 and Greenaway, 2003). A more detailed examination of teaching material and magazines, however, reveals that although dominant ideological and political concerns may have encouraged particular emphases in propaganda, the main elements persisted across decades. The main themes of temperance teaching survived from their introduction in the $1830 \mathrm{~s}-$ that ruin, illness, and poverty result from alcohol. So children were regularly invited to consider serious and perhaps frightening dangers: drink takes money you can ill afford, destroys your health, and it is (for religious, ethical and self-esteem reasons) wrong and dangerous to overindulge in alcohol. 'Ruin' here refers to moral rather than financial disgrace, and recalls the heavily religious moralising of much of the nineteenth-century temperance movement. But the concept of being made less than human, less than a rational being, by drink need not rely upon religious belief. Much material from the later nineteenth and early twentieth centuries considers the 'moral' argument from a quasi-rational standpoint, with a set of lantern slides showing, for example, the difference between a boy and a dog by a set of steps illustrating the exercise of willpower to adopt rational behaviour. Where the dog only thinks 'I am' or 'I can,' the boy is capable of moving up to 'I will.'

The economic argument could also rely on the simple assertion of slogans such as 'Drink Steals the Children's Food.' But the question of the cost of drinking was also, from the early days of the organisation, addressed in terms of critical examination. Young people might well be only too aware from their own experience of the connection between drinking and financial hardship, and the elaboration of this link 
featured in formats such as lectures, stories, poems, articles, acrostics, and even jokes, consistently. Some of the material presented to children who would not yet be holders of household budgets required them to enter into perhaps surprisingly 'adult' calculation of financial advantages. In 1904, for example, the suggested blackboard lesson plan, 'How Jack's Father Spent the Beer Money' encouraged children to take a critical look at a household's spending, showing with a diagram a breakdown of family expenditure with and without the title's 'beer-money.' Jack and his family could have a holiday, in the latter case, as well as affording new furniture and insurance. (Sindall, 1904, 95).

Much material designed to inform children about the risks of alcohol today focuses on health, and this also formed part of temperance teaching for young members of the Band of Hope. Children were given detail about the physiological effects of alcohol, often linking this to disease, and illustrated by drawings, photographs or lantern slide images. These ranged from gruesome diseased stomachs and livers, to assertions such as 'Strong Drink is Not Nourishing,' attributed to eminent doctors. With the focus on 'scientific temperance' from the 1880 s this aspect of temperance teaching took a much higher profile, intersecting with concerns about national deterioration to ensure that Band of Hope volunteers in the Schools Scientific Temperance Teaching Scheme from the 1880s onwards presented millions of lessons within the state school curriculum. Simple experiments had always taken place since in some Band of Hope sessions to isolate the alcohol in drinks, and establish its supposed harmful nature, and by the end of the century scientificallyfocused textbooks, articles and examinations, as well as lectures, emphasised the physiological and psychological arguments for total abstinence. As well as informing the future behaviour of the young scientists, such instruction was also designed to 
help them to be more effective campaigners when arguing with drinkers, who were not to be underestimated, 'some of the arguments are meant in real earnest, and we ought to be ready to reply to them' (Glasspool, 1891, 85).

\section{CHILDREN AND THE NATION}

From the early days of the temperance movement, propaganda directed at both adults and children had considered the cost of alcohol to the country, in terms of social disorder and crime, waste of resources, and Britain's public image abroad. But by the later nineteenth century concerns about national deterioration and an increased belief in the importance of legislation meant that children were exposed to much more discussion of such issues, and the national good more generally. For example, William Hoyle, a noted writer on temperance economics, frequently contributed articles on 'The Drink Traffic' to Onward. Filled with statistics about drink expenditure, national debt, spending on rent, clothing and food, an 1882 example presents complex information by simplified comparison. 'During the twelve years ending 1881, the people of the United Kingdom have spent as much money in intoxicating liquors as would have paid off our entire National Debt and bought up all the railways and left $£ 112,000,000$ to spare'. vi The value of and use of money was often stressed: in 1903 the magazine Onward had featured a photograph of the display put on by Salford Band of Hope children concerning the 'National Drink Bill' of $£ 189,000,000$. Contrasting displays and banners presented the amounts spent 'in other and useful directions'. 'vii

Children were regularly invited to consider the wider economic costs of alcohol, as well as the immediate costs to their families. 
Young Band of Hope members were often expected to understand quite complex material about the relationship between taxation, income from duty on alcoholic drinks, and the costs of 'the prisons, the reformatories, the workhouses, the lunatic asylums which are necessary in consequence of this drinking habit.' Their aid, as children, was presented as vital, ' the more we persuade people to give up drinking ... the sooner will our nation rise higher and higher in the opinion of the other nations of the earth.' (Glasspool, 82; 84).

Song titles such as 'Wake Up, John Bull' (1868), 'Shut the Drink Saloon' (1869) and the even more uncompromising 'Stop the Drinking-Trade' (1885) show that even in their entertainments children had been encouraged to consider government policy on alcohol critically since the 1860 s. With movements for increased regulation of the drink trade, articles in their magazines discussed licence regulation, draft bills raising the age at which children could be sold drink, and even compensation for publicans' loss of business, in extensive detail. . In 1903 a Licencing Bill was introduced which sought to strengthen teh power of local magistrates to reduce local outlet density. Controversially, however, it proposed that anyone whose licence was refused renewal by loacl magistrates should be compensated for their loss of livelihood. This was a complex debate for adults, but Onward discussed this in depth. In June, four pages were covered by two related items which show how informed children were about policy debate. A fairly complex article by Sir Victor Horsley, F.R.S. criticising the government's intention to introduce a compensation act was followed by a 22 verse comic narrative poem about an exploitative publican, 'Timothy Skeet's claim for compensation.' (June, 1903, 90-93). The issue was returned to in other issues through the year, and children encouraged to discuss it with adults who could bring influence to bear. Despite intensive debate, the bill was passed in the next year, but 
some of the temperance movement's successes showed that action was possible and effective, on a larger stage. For example, the passing of the Child Messenger Act at the end of 1901, extensively lobbied for in temperance groups including the Band of Hope, was celebrated in a full Onward page in January 1902 (7) and discussed in an editorial in February (30).

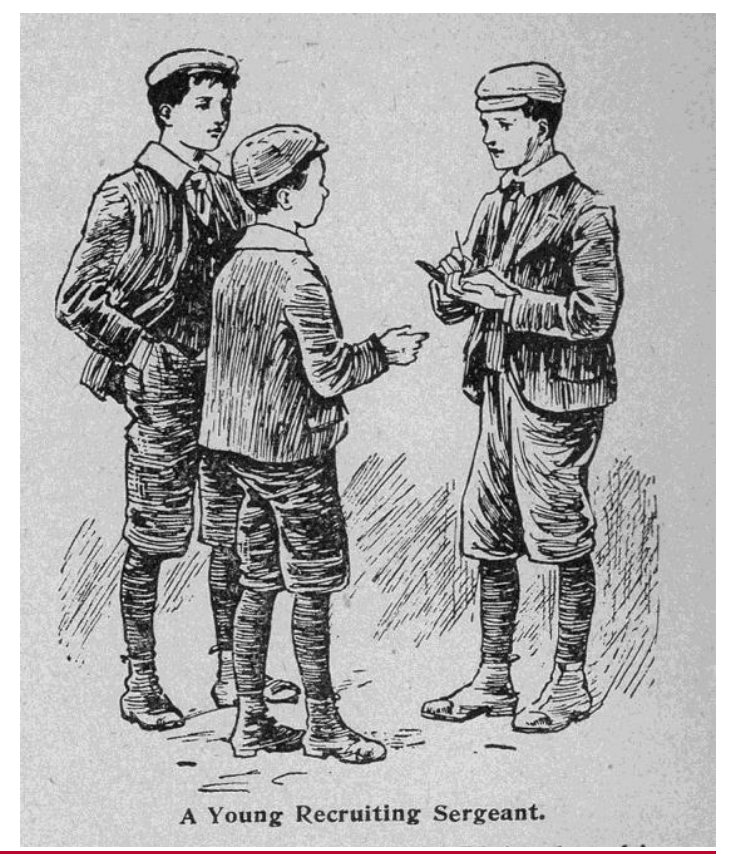

When children were encouraged to think of themselves as young recruiting sergeants for temperance, gaining new members, it is clear that much was expected of them in terms of action. A magazine series on citizenship in 1903 featured a boy asking his father 'how long will it be before we boys can vote - to elect Members of Parliament and so on?' Father tells him that in the meantime there are many ways in which boys and girls can be good citizens, and in the next month's issue, after an approving mention of female suffrage and linking it with more support for teetotal legislation, father gives some principles,

First, good citizens ought to be people of good character, who obey the laws, and see that others do so; second, they ought to see that good laws are made; third, 
they ought to do their share towards supporting the government; fourth, they ought to respect the rights of others; fifth, they ought to do all they can for the good of their country. viii

Olsen (2013) speaks of the young Band of Hope members as encouraged to be 'child exemplars,' but I would argue that their influence was expected to reach more widely. Not only were they to act as models to individual adults as well as children, but, familiar with social concepts, they were encouraged to believe that they could act to influence public opinion and policy. The children in the 1911 action recitation 'A Million More,' for example, were planting metaphorical gardens as a form of social responsibility, 'Though seeds of truth be sown today by hands of children small,/The scythe of time shall reap at last a harvest blest for all. 'ix The children waiting until they could vote teetotal candidates into Parliament show that young members of the Band of Hope expected to take a part in steering the ship of policy - or the lifeboat.

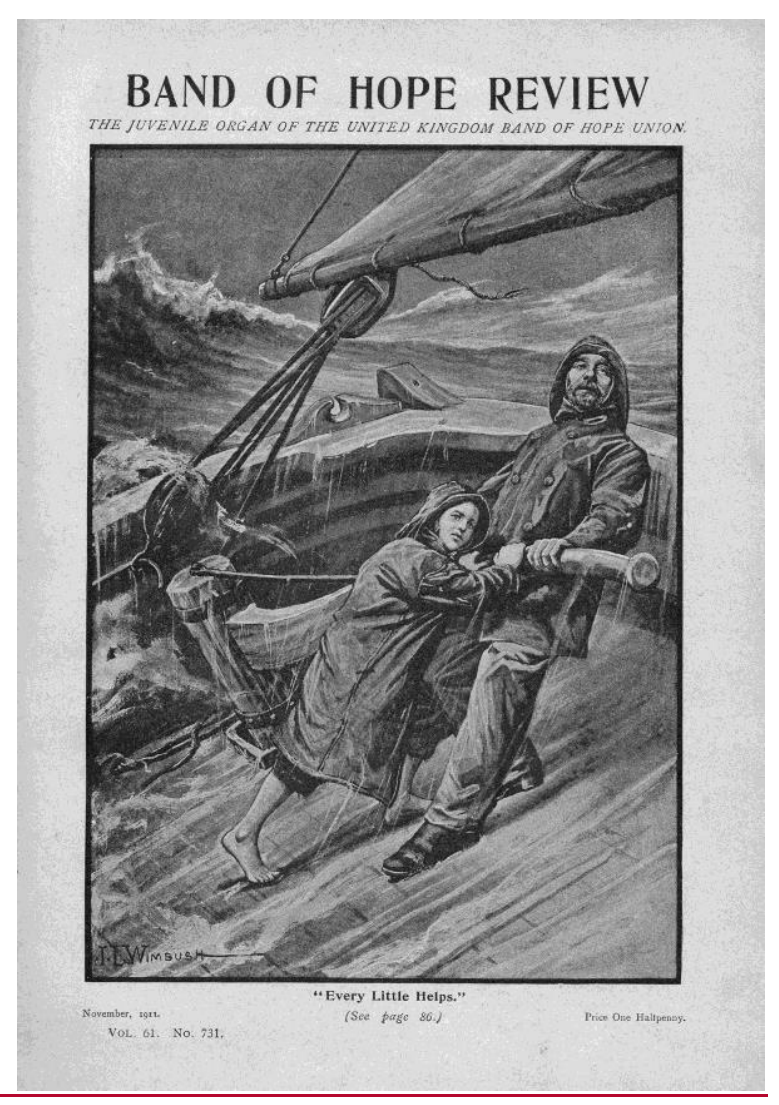


The period of World War One presents a particularly interesting case-study of the Band of Hope, with children's work continuing and numbers holding fairly strong despite the loss of many male workers and wartime restrictions, black-outs, and other disturbances to 'normal' life to contend with. The organisation simultaneously took on the task of printing and distributing millions of pledges, posters, and handbills to adults, both military and civilian, to advance the temperance cause - and lobbied tirelessly to persuade the government, later through the Central Control Board, to introduce prohibition (see Nicholls, 2011 and Duncan, 2013). Material for voluntary workers leading meetings (largely women, as the war continued) emphasised the similarity between the war against the Germans and the war against alcohol, and showed how children could help to win the latter fight, at least. Almost all songs produced during this period were martial, such as 'Recruiting we will go,' 'Battling with the Foe,' 'A Song of Victory,' 'Temperance Army Song,' and 'Your Country's Call.' These particular titles all featured in Temperance Festival Music published by the London-based United Kingdom Band of Hope Union in 1916. This was but one example of the material published for children: $\mathrm{n}$ the same year the same publisher advertised Ammunition for the Temperance War: Music, Recitations \& Dialogues suitable for the present crisis, for example. New slogans were developed to reflect this assertive mood, such as 'For a Sober Nation' and 'Abstinence: the foundation of a Better Future.' Children as well as adults took to the streets, not only continuing their usual marches, processions and other public events but also leaving leaflets in public places and recruiting centres, and setting up street stalls to invite civilian and military passers-by to sign the pledge and help to win the war. Suggested material for children's activities encouraged them to dress as military or nursing figures, 
adding their own anti-drink messages to those of Lloyd George and Lord Kitchener as they performed the roles of the adults who were saving the country.

Figure 6, above, presents a clear metaphor for the role of children in the temperance movement, as it was presented to them by the Band of Hope. Children could not replace adult workers, be they campaigners or helmsmen, but they could provide valuable aid in their work and, importantly, learn to take over from them when necessary. The key point is that the child here is actually helping to steer the ship (a lifeboat, one presumes, given the prevalence of this metaphor). This is a particularly significant role: to steer is to help to direct, rather than merely to follow, and to consider oneself responsible for the safety of those on board. The inference is that children were encouraged, as I have shown, to consider where the ship of state should be going, how citizens should behave, and whether direction, or policy, should be changed. The world as presented to them in their weekly Band of Hope meetings was a clear, if unduly black and white, one, and the presentation of external threat in the dramatic terms of tempests and stormy seas operated as a powerfully integrative factor, providing a sense of joint mission and even empowerment for the readers and viewers, as Douglas and Wildavsky (1983) suggest. The cultural climate has changed radically since then in many ways, and a significant change is our view of childhood. Paradoxically, we now, perhaps, accord children less respect in terms of their potential to take responsibility, challenge norms and act to influence society for the better. 


\section{LIST OF REFERENCES}

Berridge, V. (2013) Demons: our changing attitudes to alcohol, tobacco, \& drugs. Oxford: Oxford University Press.

Brown, C. G. (2013) The death of Christian Britain: understanding secularisation, 1800-2000. London: Routledge.

Douglas, M. and Wildavsky. A.(1983) Risk and Culture: An Essay on the Selection of Technological and Environmental Dangers. Berkeley: University of California Press

Duncan, R. (2013) Pubs and Patriots: The Drink Crisis in Britain during World War One Liverpool: Liverpool University Press.

Glasspool, A.J. (1891) The Band of Hope Companion: A Handbook for Band of Hope Members. Biographical, Historical, Scientific, and Anecdotal. (2nd edition) London: S.W. Partridge \& Co.

Greenaway, J. (2003) Drink and British Politics since 1830: a Study in Policy-Making Basingstoke: Palgrave.

Guzke, D.W. (1984) "The Cry of the Children': The Edwardian Medical Campaign Against Maternal Drinking' British Journal of Addiction (79), 71-84.

Harrison, B. (1994) Drink and the Victorians: The Temperance Question in England 1815-1872. (2nd edition) Keele: Keele University Press.

McAllister, A. (2011) "'The lives and the souls of the children": the Band of Hope in the North West,' Manchester Region History Review (22), 1-18.

McAllister, A. (2014) Demon Drink? Temperance and the Working Class. Amazon digital services. E-book.

Nicholls, J. (2011) The Politics of Alcohol: A History of the Drink Question in England Manchester: Manchester University Press.

Olsen, S. (2014) Juvenile Nation: Youth, Emotions and the Making of the Modern British Citizen, 1880-1914. London: Bloomsbury.

Palmer, L. (Mary Louise Peebles) (1904) The Little Captain; A Temperance Tale. Lonond: S.W Partridge \& Co. Ltd.

Savage, J. (2008) Teenage: The Creation of Youth, 1875-1945. London: Pimlico

Shiman, L.L. (1973) 'The Band of Hope: Respectable Recreation for Working-Class Children.' Victorian Studies, 17 (1), 49-74. 
Sindall, R,W. (1904) The Band of Hope Blackboard: a simple treatise on the art and principles of blackboard teaching as applied to the weekly meetings of the Band of Hope. London: The Sunday School Union.

Springhall, J. (1977) Youth, Empire, and Society: British Youth Movements, 18831940. London; Croom Helm.

Waites, A. and Hunter, R. (1985) The Illustrated Victorian Song Book. London: Michael Joseph. .

Wilkinson, I. (2001) Anxiety in a Risk Society London: Routledge.

Williams, G.P. and Brake, G.T. (1980) Drink in Great Britain 1900-1979. London: Edsall.

\footnotetext{
${ }^{i}$ This song was originally a poem by Henry Clay Work (1832-84) of Connecticut, first set to music and performed in the USA in 1858, according to Waites and Hunter (1985). It became very popular in the UK subsequently: the first example I have found is printed in the children's magazine Onward in April, 1867.

ii Figures for membership are taken from annual reports of the UK Band of Hope Union.

iii Band of Hope Chronicle, April, 1881, 61.

iv All songs mentioned in this article are from the monthly children's magazine Onward (1865-1910)

${ }^{v}$ See Olsen, Juvenile Nation, for more on this point.

vi Onward, September, 1882, pp. 134-5: 134.

vii Onward, November 1903, p.171. The calculation of such consumption figures, sometimes with average intake, was a frequently used device in temperance propaganda.

viii 'Young Citizens,' Band of Hope Review, January1903, 6, and 'Good Citizenship,' Band of Hope Review, February1903, 15.

ix 'A Million More,' Band of Hope Review, May 1911, 40.
} 